\title{
Age and Growth of Red Porgy, Pagrus pagrus from the Island of Gökçeada, North Aegean Sea
}

\author{
Hakan Ayyıldız ${ }^{1}$, Aytaç Altın ${ }^{1}$ (D), Bayram Kızılkaya² \\ Cite this article as: Ayyıldız, H., Altın, A., Kızılkaya, B. Age and growth of red porgy, Pagrus pagrus from the Island of Gökçeada, North aegean sea. \\ Aquatic Sciences and Engineering, 35(2), 57-63
}

ORCID IDs of the authors: H.A. 0000-0002-6442-0421; A.A. 0000-0002-0327-6665; B.K. $0000-0002-3916-3734$

'Çanakkale Onsekiz Mart University, Gökçeada Faculty of Applied Sciences, Department of Fisheries Technology,

Çanakkale, Turkey

${ }^{2}$ Çanakkale Onsekiz Mart University, Faculty of Marine Sciences and Technology, Çanakkale, Turkey

Submitted:

03.12.2019

Revision Requested: 18.02.2020

Last Revision Received:

19.02.2020

Accepted:

01.03.2020

Online published:

12.03.2020

Correspondence:

Hakan Ayyıldız

E-mail:

ayyildizhakan@gmail.com

(C) Copyright 2020 by Aquatic Sciences and Engineering Available online at https://dergipark.org.tr/ase

\section{ABSTRACT}

The aim of this study was to describe the age, growth and relationships between otolith morphometry and fish length, weight and age of the red porgy, Pagrus pagrus. This study was carried out from the shores of Gizli liman to Kefalos Cape in the north of Gökçeada Island, between March and June 2018. The samples were collected at depths of 40-120 $\mathrm{m}$ by long lines. The 66 individuals obtained from red porgy ranged in total length $(T L)$ from 13.5 to $50 \mathrm{~cm}$. The calculated lengthweight relationship was determined as $\mathrm{W}=0.016 \mathrm{TL}^{2.9653}\left(\mathrm{R}^{2}=0.98\right)$. Individual ages were macroscopically determined by counting the annuli of sagittal otoliths. Estimated ages ranged from 1-12 years. The von Bertalanffy growth curve was fitted to the age/total length data as follows: $L \infty=51.48$ $\mathrm{cm}, \mathrm{K}=0.18$ and $\mathrm{t}_{0}=-0.27$. The red porgy sagittal otolith length, width and mass were measured between $4.96-14.72 \mathrm{~mm}, 3.49-7.85 \mathrm{~mm}$ and $0.0199-0.2460 \mathrm{~g}$, respectively. No significant differences in otolith morphometry were found between left and right otoliths. This study provides valuable data for the stock assessment of common pandora in the fishing grounds of Gökçeada Island located in the North Aegean Sea.

Keywords: Age structure, otolith morphometry, Pagrus pagrus, Gökçeada

\section{INTRODUCTION}

Age and growth data provide important information about both individuals and their populations (Michael et al., 2013). Thus, determining the age and growth of the fish species has been and will continue to be one of the most important activities carried out by fisheries biologists (Jackson, 2007). Age and growth information are helpful in describing the present status and past history of fish populations along with the future program of the fishery management (Khan \& Khan, 2014). Otoliths are highly useful anatomical structures because they provide the most accurate estimates in determining the age of many fish species (Campana \& Thorrold, 2001). Otoliths are used in balance and/or hearing in all bony fishes (Campana, 1999). In the inner ear, there are three pairs of otoliths called lapillus, asteriscus and sagitta (Green et al., 2009; Tuset et al., 2008). These are natural data loggers that record information about growth and environment at different temporal scales into their microstructures and chemistry (Campana, 1999; Kalish, 1989). In addition, otoliths show a complete chronological record of the life of fish (Campana, 1999). Otoliths continue to grow throughout the life of the fish, and this growth occurs by the accumulation of protein and calcium secreted by the macular cells surrounding the surface of the otolith (Campana \& Neilson, 1982). The use of otoliths to determine the age of the fish began in 1899 with the observations of Reibisch (Campana, 1999). Age estimates were made by counting the macro bands representing the annual growth rings in the otoliths of the adult individuals of some tropical fish.

The red porgy, Pagrus pagrus, is a demersal marine fish associated with a variety of temperate to 
subtropical habitats (Labropoulou et al., 1999; Vassilopoulou \& Papaconstantinou, 1992). This species is distributed throughout the Atlantic Ocean and Mediterranean Sea at depths of 18 to $280 \mathrm{~m}$ (Manooch \& Hassler, 1978). Adults of this species inhabit rocky or gravel habitats (Alekseev, 1982; Manooch \& Hassler, 1978). This species is a protogynous hermaphrodite that reveals an unbalanced sex ratio in favor of females (Manooch \& Hassler, 1978; Vassilopoulou \& Papaconstantinou, 1992). Red porgy is a carnivorous fish species that can reach a weight of up to $15-20 \mathrm{~kg}$. It has great economic importance for coastal fisheries in the Turkish waters. According to Türkstat data, commercial landings of red porgy have experienced a serious decline since 2009. Based on these data, it can be said that red porgy stocks are being overexploited.

The red porgy is listed in the IUCN Red List of Threatened Species as a species of least concern, with a recommendation of improved and targeted fisheries regulations and protection for this species (Russell et al., 2014). It is important to study these species, broadly distributed and economically important, in order to implement management policies. The purpose of our study was to determine the age of red porgy accurately in order to develop age-length keys and growth model from Gökçeada Island, Turkey. We also examined the relationship between otolith morphometric measurements (length, width, and mass) and the total length of the fish.

\section{MATERIAL AND METHODS}

This study was carried out from Gökçeada Island, Turkey (Figure 1). Samplings were conducted using long lines, from 40-120 m depths between March and June 2018.

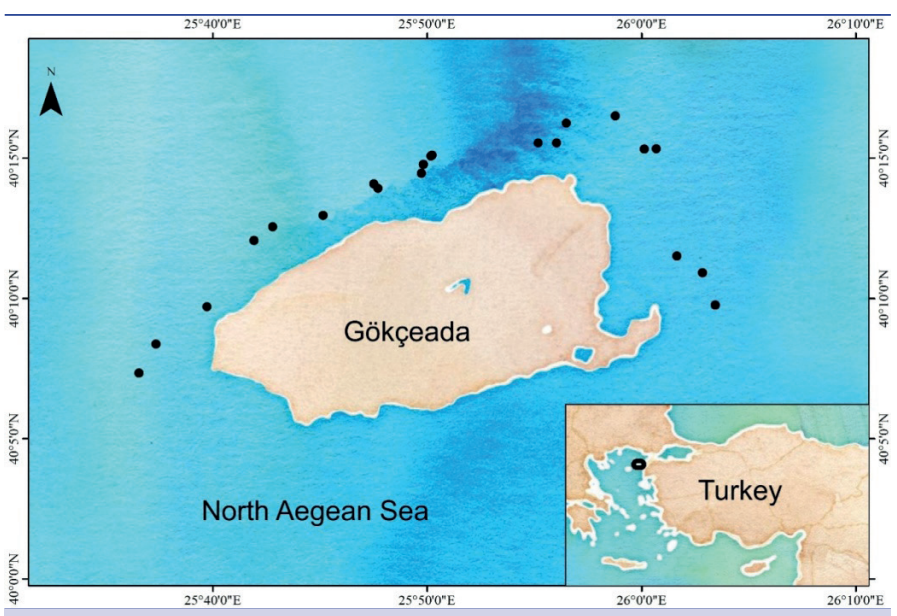

Figure 1. Sampling stations where red porgy, Pagrus pagrus were collected with long lines from the island of Gökçeada, Turkey, March - June 2018.

\section{Length-weight relationships}

The red porgy was measured for total length (TL) and total weight (W). Sexes were determined using morphological examination in the laboratory. The Mann-Whitney $U$ test was applied to examine the differences between sexes according to the total length. The relationship between the total length and the weight was calculated for each sex separately using a power function:
$\mathrm{W}=\mathrm{aTL} L^{\mathrm{b}}$

where, $b$ is the regression coefficient and $a$ is the regression constant. The regression parameters $a, b$ and the coefficient of determination $\left(R^{2}\right)$ were estimated for all individuals and for each sex. The allometric index value (b) was compared to the theoretical value of 3 by a t-test (Zar, 1984).

\section{Age and growth}

Sagittal otoliths of red porgy were extracted, dried and stored in eppendorf tubes. One otolith was randomly selected and immersed in a plastic vial with glycerine solution for an hour. Sagittal otolith annual rings were counted from the core to the outer edge under a light microscope (Figure 2). Two readers independently counted the annual rings without prior knowledge of fish length. Estimates of the precision of growth ring counts between readers were determined using the average percentage error (APE) of (Beamish \& Fournier, 1981) and coefficient of variation (CV) (Chang, 1982).

The von Bertalanffy growth curve was fitted to the length at age data using non-linear least squares parameter estimation (Von Bertalanffy, 1938);

$T L=L_{\infty}\left[1-e^{(-K(t-t 0))}\right]$

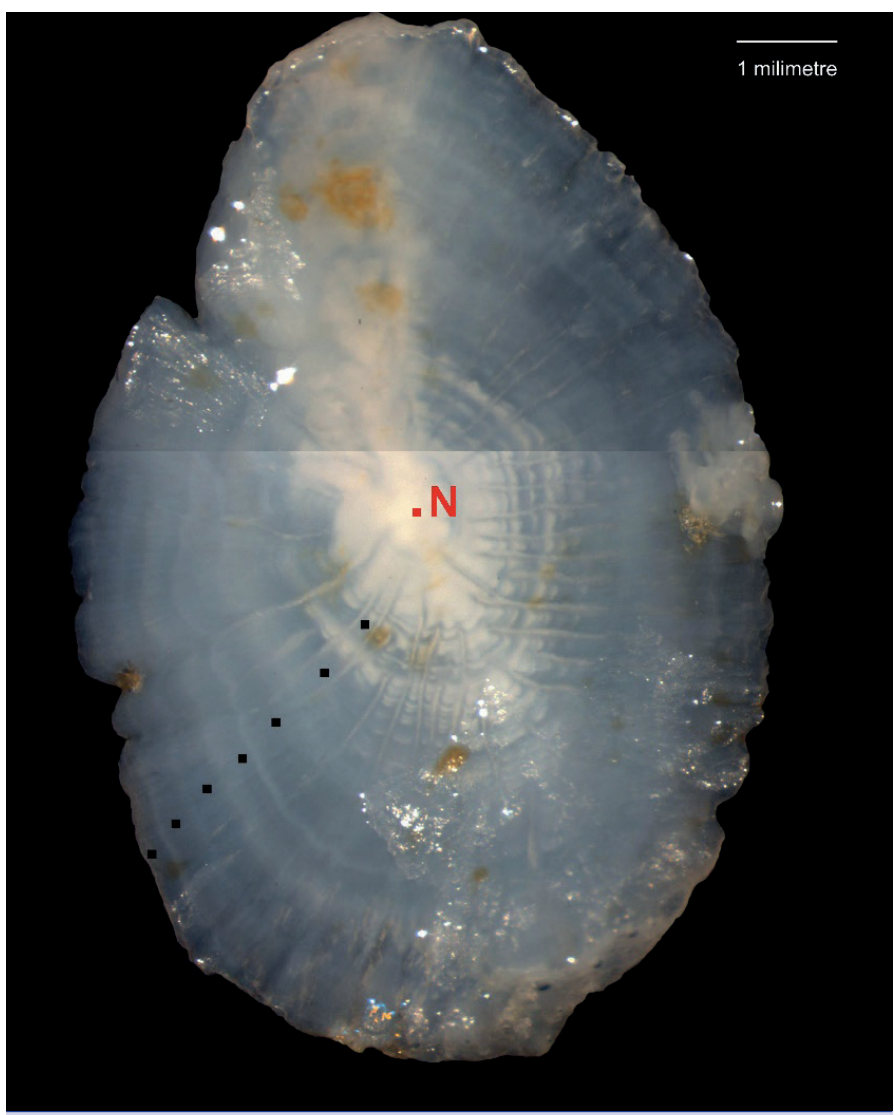

Figure 2. Image of the annual rings seen in a sagittal otolith of red porgy, Pagrus pagrus collected from Gökçeada, Turkey. This fish was aged at 7 years and had a total length of $37.5 \mathrm{~cm}$ female. 
where $T L$ is the fish length at age $t, L_{\infty}$ the theoretical asymptotic length, $K$ the growth rate coefficient, and $t_{0}$ the theoretical age when the fish length is zero.

\section{Otolith morphometry}

Otolith length $(\mathrm{OL})$ and width $(\mathrm{OW})$ were measured to the nearest $0.01 \mathrm{~mm}$ using $\mathrm{Q}$ Capture Imaging Software and weighed (OM) to the nearest $0.00001 \mathrm{~g}$ using a Shimadzu electronic balance. OL was defined as the longest axis between the anterior and posterior otolith edge and OW as a distance from the dorsal to the ventral edge (Figure 3). Differences between left and right otoliths were tested by paired t-test. The relationships between the fish length and the otolith morphometry were investigated. Relations between age and otolith weight were calculated using the exponential model.

\section{RESULTS AND DISCUSSION}

A total of 66 red porgy, Pagrus pagrus, were sampled from Gökçeada, Turkey. The red porgy individuals ranged in size

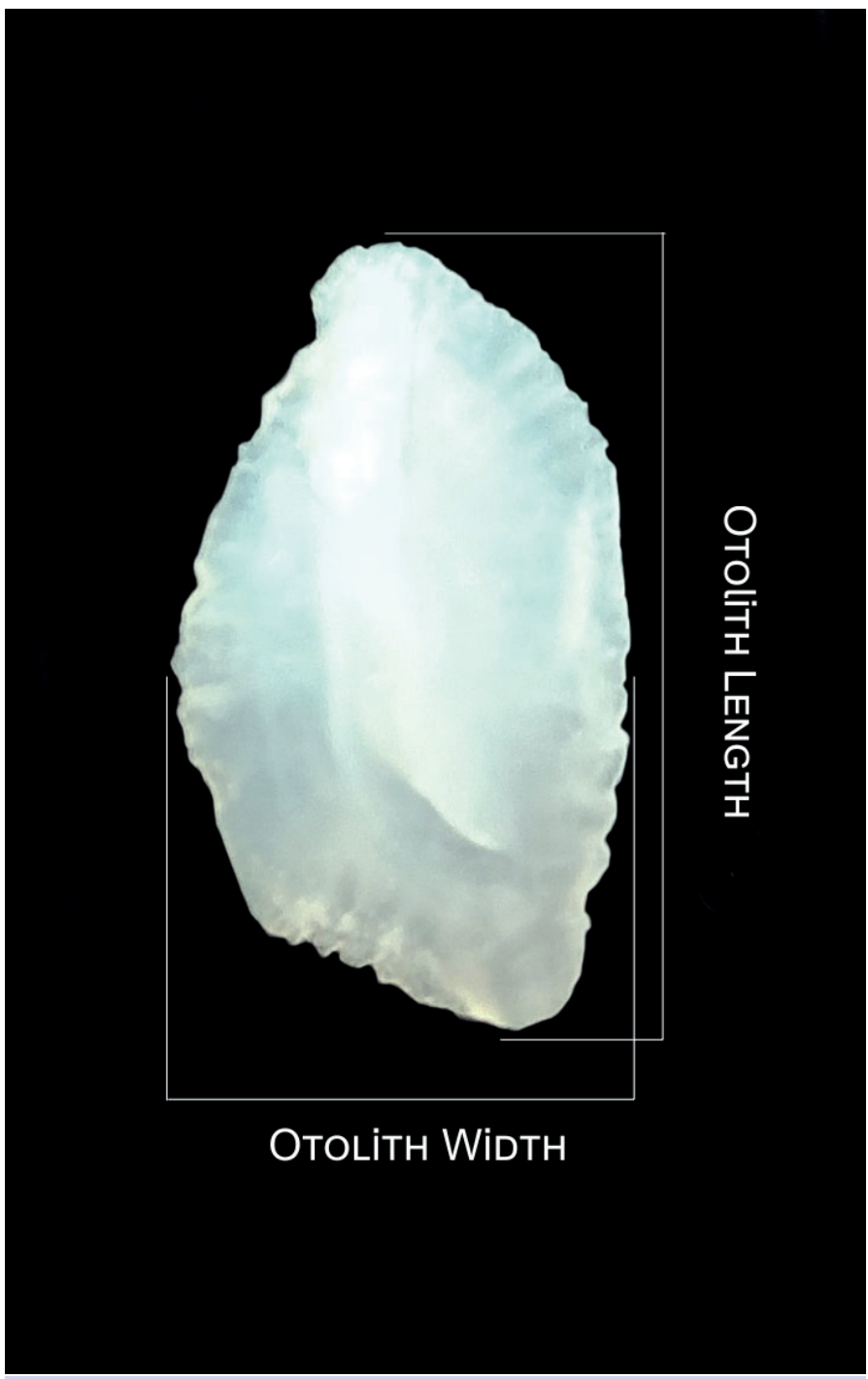

Figure 3. Morphometric measurements of red porgy sagittal otolith. from 13.5 to $50 \mathrm{~cm}$ total length (Table 1). Female and male total lengths ranged from 19.9 to $37.5 \mathrm{~cm}$ and from 13.5 to $50 \mathrm{~cm}$, respectively (Figure 4). The Mann-Whitney test revealed significant differences between sexes, regarding $T L(U=203, Z=2.2117$; $p<0.05)$. The overall male: female ratio $(M: F=1: 2)$ was biased in favor of females. The maximum length and weight reported in this study are the biggest reported values from Turkey. In their studies from Turkey Issmen et al. (2013) and Ozvarol (2014) reported that the larger individuals were 44.5 and $19 \mathrm{~cm}$ in total length, respectively.

\section{Length-weight relationships}

The parameters of the length-weight relationships are provided for each sex and all individuals in Table 2. Our data suggested that red porgy from Gökçeada showed negative allometric growth. The parameter b of length-weight relationships was significantly different from $3(p<0.05)$. The allometric exponent $b$ of females was greater than males. Females grew isometrically while males grew allometrically. Most of the previous studies have shown that red porgy showed negative allometric growth (İşmen et al., 2013; Pajuelo \& Lorenzo, 1996; Vassilopoulou \& Papaconstantinou, 1992).

\section{Age and growth}

Ages were determined successfully from 66 otoliths of common pandora that ranged in size from 13.5 to $50 \mathrm{~cm}$ TL. Based on the annual growth ring counts of red porgy otoliths, the maximum observed age was 12 years and the minimum observed age was 1 year old (Table 3 ). Most of the fish, accounting for $78.8 \%$ of the total sample, were between 2 and 4 years old. The APE and CV were calculated as $7.4 \%$ and $5.2 \%$, respectively. Only males represented age classes of older than 8 years.

The Von Bertalanffy (1957) model was used to describe red porgy growth (Figure 5). The estimated parameters of the equation were; $L_{\infty}=51.48 ; W_{\infty}=1904.7 ; K=0.1861$ and $t_{0}=-0.27$.

The calculated asymptotic length for the red porgy of the Gökçeada population shows similarity with other studies especially for the population in the Aegean Sea and the Gulf of Mexico (İşmen et al., 2013; Nelson, 1988; Vassilopoulou \& Papaconstantinou, 1992). Lower asymptotic lengths were presented for the populations in Buenos Aires, South Atlantic and in the Southern Aegean Sea (Cotrina \& Raimondo, 1997; Harris \& McGovern, 1997; Machias et al., 1998). The calculated asymptotic length values given by some authors (Cotrina \& Raimondo, 1997; Harris \& McGovern, 1997; Machias et al., 1998) are smaller than those of the older individuals obtained from our study. These differences may be due to the size range of the sampled fish and/or the environmental factors where the samples were collected. The findings observed in this study mirror those of previous studies (Hood \& Johnson, 2000; İşmen et al., 2013; Potts \& Manooch III, 2002) that found a lower $k$ value indicating a slower growth rate.

\section{Otolith morphometry}

Otolith length, width and mass ranged between 4.96-14.72 mm, $3.49-7.85 \mathrm{~mm}$ and $0.0199-0.2460 \mathrm{~g}$, respectively (Table 4). No significant differences in otolith morphometrics were found be- 
Table 1. Summary of the total lengths in centimeters of red porgy collected from Gökçeada. The number of specimens ( $n$ ) and range, mean, and standard deviation of the mean (SD) for total length are provided.

\begin{tabular}{lcccccccccccccccc}
\hline \multirow{2}{*}{$\begin{array}{l}\text { Capture } \\
\text { Date }\end{array}$} & \multicolumn{1}{c}{ Female } & $\mathbf{n}$ & Min. & Max. & Mean & SD & $\mathbf{n}$ & Min. & Max. & Mean & SD & $\mathbf{n}$ & Min. & Max. & Mean & SD \\
\hline March 18 & 3 & 26.3 & 27.1 & 26.63 & 0.42 & $\ldots$ & $\ldots$ & $\ldots$ & $\ldots$ & $\ldots$ & $\ldots$ & $\ldots$ & $\ldots$ & $\ldots$ & $\ldots$ \\
April 18 & 33 & 19.9 & 37.5 & 26.04 & 3.26 & 12 & 19.9 & 50 & 31.88 & 8.55 & 10 & 18.1 & 22 & 19.59 & 1.18 \\
May 18 & $\ldots$ & $\ldots$ & $\ldots$ & $\ldots$ & $\ldots$ & 6 & 13.5 & 37.4 & 25.65 & 8.53 & 1 & 19.6 & 19.6 & 19.6 & $\ldots$ \\
June 18 & $\ldots$ & $\ldots$ & $\ldots$ & $\ldots$ & $\ldots$ & $\ldots$ & $\ldots$ & $\ldots$ & $\ldots$ & $\ldots$ & 1 & 22.1 & 22.1 & 22.1 & $\ldots$
\end{tabular}

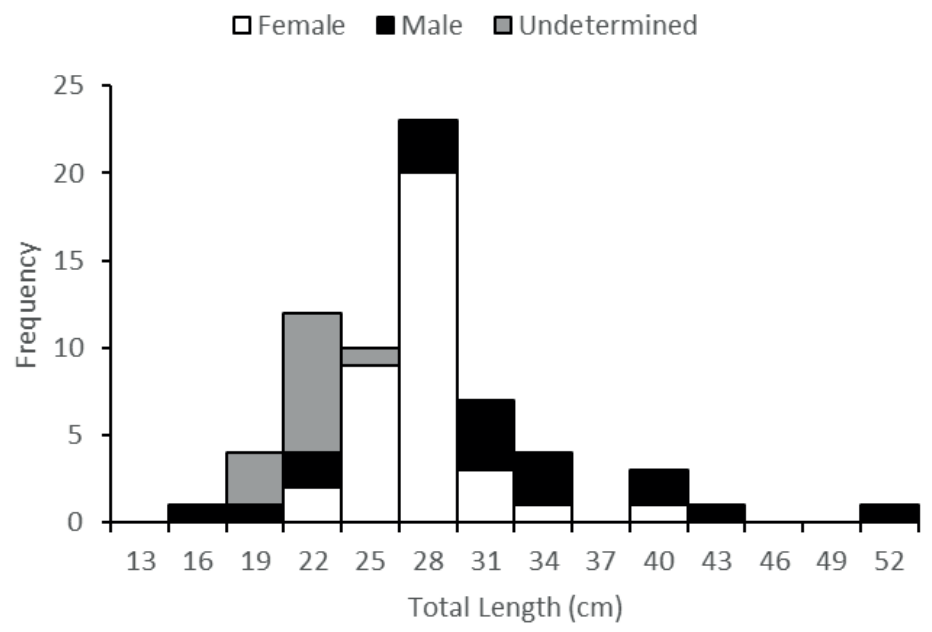

Figure 4. Length-frequency distribution of males and females of red porgy collected from Gökçeada, Turkey.

Table 2. Parameters of the length-weight relationships for males, females, and all individuals of red porgy from Gökçeada, Turkey.

\begin{tabular}{llcccc}
\hline & $\mathbf{n}$ & $\mathbf{a}$ & $\mathbf{b}$ & $\mathbf{R}^{\mathbf{2}}$ & $\mathbf{P}$ \\
\hline Female & 36 & 0.0129 & 3.031 & 0.964 & $<0.01$ \\
Male & 18 & 0.0210 & 2.887 & 0.996 & $<0.01$ \\
Undetermined & 12 & 0.0267 & 2.784 & 0.692 & $<0.01$ \\
All & 66 & 0.0160 & 2.965 & 0.986 & $<0.01$
\end{tabular}

Table 3. Age-length key for red porgy from Gökçeada, Turkey.

\begin{tabular}{|c|c|c|c|c|c|c|c|c|c|c|c|}
\hline \multirow{2}{*}{ Total Length $(\mathrm{cm})$} & \multicolumn{10}{|c|}{ Age (Year) } & \multirow[b]{2}{*}{$\mathrm{n}$} \\
\hline & 1 & 2 & 3 & 4 & 5 & 6 & 7 & 8 & 9 & 12 & \\
\hline $13-16.9$ & 1 & & & & & & & & & & 1 \\
\hline $17-20.9$ & 1 & 10 & 3 & & & & & & & & 14 \\
\hline $21-24.9$ & & & 12 & & & & & & & & 12 \\
\hline $25-28.9$ & & & 11 & 14 & & & & & & & 25 \\
\hline $29-32.9$ & & & & 2 & 2 & 1 & & 1 & & & 6 \\
\hline $33-36.9$ & & & & & 1 & 1 & 1 & & & & 3 \\
\hline $37-40.9$ & & & & & & & 2 & 1 & & & 3 \\
\hline $41-44.9$ & & & & & & & & & 1 & & 1 \\
\hline $45-48.9$ & & & & & & & & & & & 0 \\
\hline $49-52.9$ & & & & & & & & & & 1 & 1 \\
\hline$n$ & 2 & 10 & 26 & 16 & 3 & 2 & 3 & 2 & 1 & 1 & 66 \\
\hline
\end{tabular}




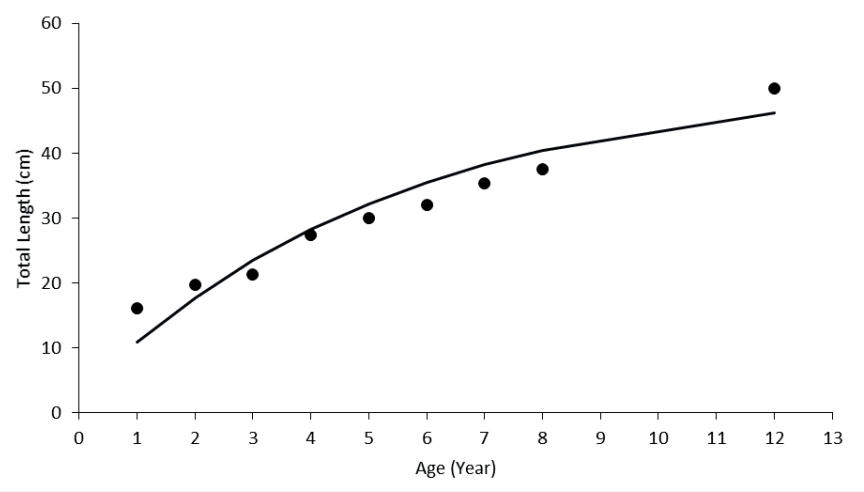

Figure 5. The von Bertalanffy growth curves for red porgy from Gökçeada, Turkey.

tween left and right otoliths (paired t-test, $\mathrm{P}>0.05)$. OL, OW and OM showed significant linear relations with the TL (Table 5). The relationship between otolith morphometry and age is shown in Figure 6. An exponential model explains between $80 \%$ and $91 \%$ of the variation in age.

Otolith morphology has proven to be a powerful tool in species discrimination of many teleost fishes (Rani et al., 2019; Volpedo \& Echeverria, 2003). This paper investigates the relationship of fish $\mathrm{TL}$ and age with otolith morphometrics (OL and $\mathrm{OW}$ ) by a power model and OM by linear regression. The results of this study indicate that $\mathrm{OL}, \mathrm{OW}$ and the $\mathrm{OM}$ were linearly correlated to the fish TL. The OM was found to be a better parameter than the others $(\mathrm{OL}$ and $\mathrm{OW})$ in estimating fish length and weight. These results are consistent with those of other studies and suggest that fish size and weight could be estimated using the otolith morphometrics (Altin \& Ayyildiz, 2018; Ayyildiz \& Altin, 2018; Ayyildiz et al., 2014; Yilmaz et al., 2015). In addition, the best model for predicting the fish age of common pandora was found to be OM in this study.

\section{CONCLUSION}

In conclusion, the findings of the present study show that total length and weight can be estimated from its otolith morphometric measurements or vice versa. Information about the otolith morphometry could prove to be an important tool for the identification of fish species and determines the prey size that is obtained from the stomach contents of piscivorous predators. In addition, most of the individuals we caught in our study were between 2 and 4 years old. There are no restrictions on fishing for red porgy in Turkish waters nor on the amount that can be caught. However, as this species can reach sexual maturity at the age of 2-4 years when their length corresponds to about $24 \mathrm{~cm}$, the results of this study indicate that it is proper to catch this species in this region when the fish are between 2 and 4 years old. The results provide essential information needed for management policies of red porgy from the North Aegean Sea. Further studies will be required on the age, growth and reproduction of this species to enable effective and sustainable management of red porgy fisheries.

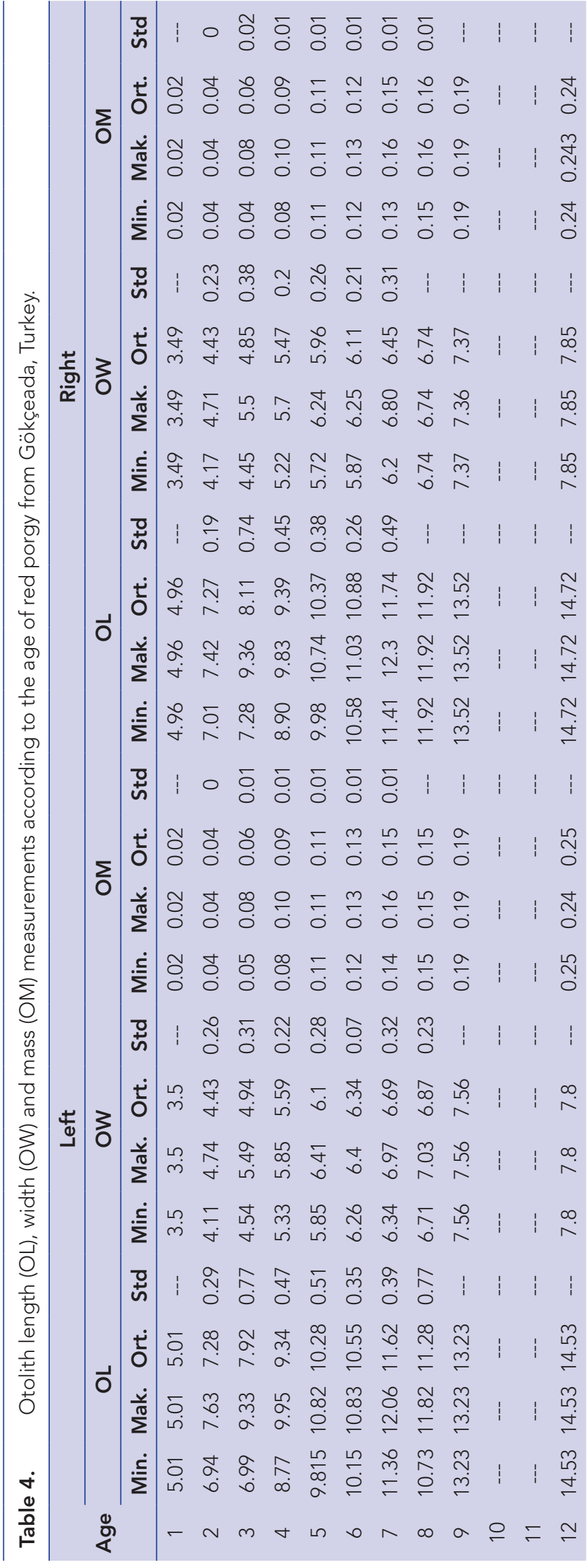


Table 5. Parameters of the relationships between the otolith morphometry and the fish total length and weight for red porgy from Gökçeada, Turkey

\begin{tabular}{ccccccc}
\hline Otolith-fish relationships & Model & $\mathbf{n}$ & $\mathbf{a}$ & $\mathbf{b}$ & $\mathbf{r}^{2}$ & $\mathbf{p}$ \\
\hline TL - OL & Linear & 66 & -8.49 & 3.83 & 0.96 & $<0.05$ \\
TL - OW & Linear & 66 & -15.66 & 7.65 & 0.96 & $<0.05$ \\
TL - OM & Linear & 66 & 11.97 & 158 & 0.99 & $<0.05$ \\
W - OL & Exponential & 66 & 0.058 & 3.79 & 0.96 & $<0.05$ \\
W - OW & Exponential & 66 & 0.105 & 4.56 & 0.96 & $<0.05$ \\
W - OM & Exponential & 66 & 11415 & 1.53 & 0.98 & $<0.05$ \\
n= number of specimens, a slope of the regression line, b= -intercept, $r^{2}=$ coefficient of determination; TL= fish total length, OL= otolith length, OW= otolith \\
width, OM= otolith mass
\end{tabular}

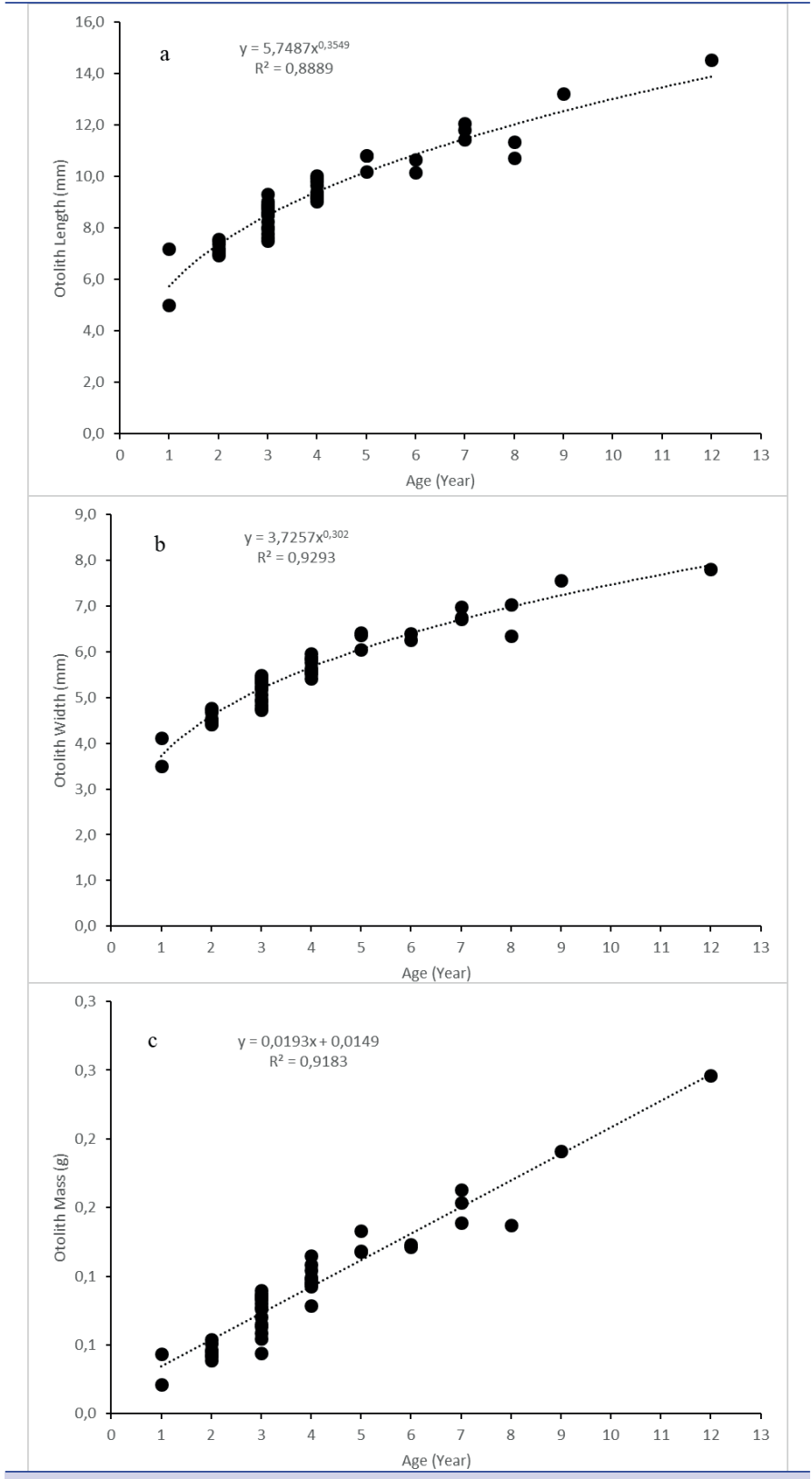

Figure 6. The relationship between otolith morphometry and age for red porgy from Gökçeada, Turkey; Otolith length (a), Otolith width (b), Otolith mass (c).
Ethics Committee Approval: This study was carried out in accordance with animal welfare and trial ethics.

Conflict of Interest: Author has no conflict of interest to report.

Financial Disclosure: This study was funded by Çanakkale Onsekiz Mart University, The Scientific Research Coordination Unit, project number: FBA-2018-1406.

\section{REFERENCES}

Alekseev, F. (1982). Hermaphroditism in sparid fishes (Perciformes, Sparidae): 1. Protogyny in porgies, Pagrus pagrus, $P$. orphus, $P$. ehrenbergi and P. auriga, from West Africa. J Ichthyol, 22, 85-94.

Altin, A., \& Ayyildiz, H. (2018). Relationships between total length and otolith measurements for 36 fish species from Gokceada Island, Turkey. Journal of Applied Ichthyology, 34(1), 136-141. [CrossRef]

Ayyildiz, H., \& Altin, A. (2018). Age and growth rates at the early life stages of common pandora (Pagellus erythrinus) based on analysis of otolith microstructure. Fishery Bulletin, 116(2), 183-189. [CrossRef]

Ayyildiz, H., Emre, Y., Ozen, O., \& Yagci, A. (2014). Age and growth of Capoeta erhani (Actinopterygii: Cypriniformes: Cyprinidae) from the Menzelet reservoir, Turkey. Acta Ichthyologica Et Piscatoria, 44(2), 105-110. [CrossRef]

Beamish, R. J., \& Fournier, D. A. (1981). A method for comparing the precision of a set of age-determinations. Canadian Journal of Fisheries and Aquatic Sciences, 38(8), 982-983. [CrossRef]

Campana, S. E. (1999). Chemistry and composition of fish otoliths: pathways, mechanisms and applications. Marine Ecology Progress Series, 188, 263-297. [CrossRef]

Campana, S. E., \& Neilson, J. D. (1982). Daily growth increments in otoliths of starry flounder (Platichthys-stellatus) and the influence of some environmental variables in their production. Canadian Journal of Fisheries and Aquatic Sciences, 39(7), 937-942. [CrossRef]

Campana, S. E., \& Thorrold, S. R. (2001). Otoliths, increments, and elements: keys to a comprehensive understanding of fish populations? Canadian Journal of Fisheries and Aquatic Sciences, 58(1), 30-38. [CrossRef]

Chang, W. Y. B. (1982). A statistical-method for evaluating the reproducibility of age-determination. Canadian Journal of Fisheries and Aquatic Sciences, 39(8), 1208-1210. [CrossRef]

Cotrina, C. P., \& Raimondo, M. C. (1997). Estudio de edad y crecimiento del besugo (Pagrus pagrus) del sector costero Bonarense. Rev Invest Desarr Pesq, 11, 95-118.

Green, B. S., Mapstone, B. D., Carlos, G., \& Begg, G. A. (2009). Introduction to Otoliths and Fisheries in the Tropics. In B. S. Green, B. D. Mapstone, G. Carlos, \& G. A. Begg (Eds.), Tropical Fish Otoliths: Information for Assessment, Management and Ecology (pp. 1-22). Dordrecht: Springer Netherlands. [CrossRef] 
Harris, P. J., \& McGovern, J. C. (1997). Changes in the life history of red porgy, Pagrus pagrus, from the southeastern United States, 19721994. Fishery Bulletin, 95(4), 732-747.

Hood, P. B., \& Johnson, A. K. (2000). Age, growth, mortality, and reproduction of red porgy, Pagrus pagrus, from the eastern Gulf of Mexico. Fishery Bulletin, 98(4), 723-735.

Işmen, A., Arslan, M., Gül, G., \& Yığın, C. Ç. (2013). Otolith morphometry and population parameters of red porgy, Pagrus pagrus (Linnaeus, 1758) in Saros Bay (North Aegean Sea). Su Ürünleri Dergisi, 30(1). [CrossRef]

Jackson, J. R. (2007). Earliest references to age determination of fishes and their early application to the study of fisheries. Fisheries, 32(7), 321-328. [CrossRef]

Kalish, J. M. (1989). Otolith microchemistry: validation of the effects of physiology, age and environment on otolith composition. Journal of Experimental Marine Biology and Ecology, 132(3), 151-178. [CrossRef]

Khan, S., \& Khan, M. (2014). Importance of age and growth studies in fisheries management: Reviewed Proceeding of National Seminar on NGSV.

Labropoulou, M., Machias, A., \& Tsimenides, N. (1999). Habitat selection and diet of juvenile red porgy, Pagrus pagrus (Linnaeus, 1758). Fishery Bulletin, 97(3), 495-507.

Machias, A., Tsimenides, N., Kokokiris, L., \& Divanach, P. (1998). Ring formation on otoliths and scales of Pagrus pagrus: a comparative study. Journal of fish Biology, 52(2), 350-361. [CrossRef]

Manooch, C. S., \& Hassler, W. W. (1978). Synopsis of biological data on the red porgy, Pagrus pagrus (Linnaeus): National Marine Fisheries Service. [CrossRef]

Michael, C. Q., Mark, A. P., \& Dennis, R. D. (2013). Age and Growth. In V. Z. Alexander, L. P. Donna, \& T. M. S. Bethesda (Eds.), Fisheries Techniques. Maryland: American Fisheries Society.

Nelson, R. S. (1988). A study of the life history, ecology, and population dynamics of four sympatric reef predators ( $R$. aurorubens, $L$. campechanus, H. melanurum, and P. pagrus) on the East and West Flower Garden Banks, NW Gulf of Mexico. (PhD), North Carolina State Univ., Raleigh, N.C.
Ozvarol, Y. (2014). Length-weight relationships of 14 fish species from the Gulf of Antalya (northeastern Mediterranean Sea, Turkey). Turkish Journal of Zoology, 38(3), 342-346. [CrossRef]

Pajuelo, J. G., \& Lorenzo, J. M. (1996). Life history of the red porgy Pagrus pagrus (Teleostei: Sparidae) off the Canary Islands, central east Atlantic. Fisheries Research, 28(2), 163-177. [CrossRef]

Potts, J. C., \& Manooch III, C. S. (2002). Estimated ages of red porgy (Pagrus pagrus) from fishery-dependent and fishery-independent data and a comparison of growth parameters. Fishery Bulletin, 100(1), 81-89.

Rani, A., Rai, D., \& Tyor, A. K. (2019). Morphometrics analysis of sagitta otolith in pool barb, Puntius sophore (Hamilton, 1822). J Morphol Sci, 36(2), 085-090. [CrossRef]

Russell, B., Pollard, D., Carpenter, K. E., \& Vega-Cendejas, M. (2014). Pagrus pagrus. The IUCN Red List of Threatened Species 2014: e. T15873A788483. [CrossRef]

Tuset, V. M., Lombarte, A., \& Assis, C. A. (2008). Otolith atlas for the western Mediterranean, north and central eastern Atlantic. Scientia Marina, 72, 7-198. [CrossRef]

Vassilopoulou, V., \& Papaconstantinou, C. (1992). Age, growth and mortality of the red porgy, Pagrus pagrus, in the eastern Mediterranean Sea (Dodecanese, Greece). Vie et milieu, 42(1), 51-55.

Volpedo, A., \& Echeverria, D. D. (2003). Ecomorphological patterns of the sagitta in fish on the continental shelf off Argentine. Fisheries Research, 60(2-3), 551-560. [CrossRef]

Von Bertalanffy, L. (1938). A quantitative theory of organic growth (inquiries on growth laws. II). Human biology, 10(2), 181-213.

Von Bertalanffy, L. (1957). Von Bertalanffy L. Quantitative laws in metabolism and growth. Quarterly Reviews of Biology, 32, 217-231. [CrossRef]

Yilmaz, S., Yazicioglu, O., Yazici, R., \& Polat, N. (2015). Relationships between fish length and otolith size for five cyprinid species from Lake Ladik, Samsun, Turkey. Turkish Journal of Zoology, 39(3), 438446. [CrossRef]

Zar, J. H. (1984). Biostatistical Analysis (2 ed.). Englewood Cliffs, NJ, USA: Prentice-Hall, Inc. 